\title{
COATTAIL EFFECT STRATEGY OF GERINDRA PARTY IN 2019 CONCURRENT ELECTION
}

\author{
Ratnawati, ${ }^{1}$ Davit Romansa ${ }^{2}$ \\ Universitas Gadjah Mada
}

\begin{abstract}
:
This article tests the coattail effect theory in the general elections (concurrent elections) of Indonesia in 2019. In this election the legislative and presidential elections took place simultaneously. In this context, the article examines the effectiveness of the coattail effect theory for the Great Indonesia Movement Party (Partai Gerakan Indonesia Raya/ Gerindra) in concurrent elections in Pekalongan Regency. Through the coattail effect, Gerindra Party, which proposed Prabowo as a presidential candidate in the presidential lection, hoped to be able to provide positive benefits and increased votes in the legislative election in Pekalongan Regency. The article shows that Gerindra Party was unable to "sell" the figure of Prabowo (General Chairperson of the Gerindra Party) who ran for President in the legislative elections, because the Gerindra Party actually lost 1 (one) seat in Pekalongan Regency DPRD. All this shows that the coattail effect theory did not work well.
\end{abstract}

Keywords: Coattail effect, Gerindra Party, Concurrent Election.

Título en Castellano: Estrategia del Efecto 'coattail' del Partido Gerindra en las Elecciones Concurrentes de 2019

\section{Resumen:}

Este artículo pone a prueba la teoría del efecto 'coattail'3 en las elecciones generales (elecciones concurrentes) de Indonesia de 2019. En esa elección, las elecciones legislativas y presidenciales se realizaron de forma simultánea. En este contexto, este artículo intenta examinar la eficiencia de la Teoría del efecto 'coattail' para el Partido del Movimiento de la Gran Indonesia (Partai Gerakan Indonesia Raya/ Gerindra) en las elecciones concurrentes en Pekalongan Regency. A través del efecto 'coattail', el Partido Gerindra, proponiendo a Prabowo como candidato en las elecciones presidenciales, esperaba obtener beneficios positivos y ganar más votos en las elecciones legislativas en Pekalongan Regency. Los resultados muestran que el Partido Gerindra no fue capaz de "vender" la figura de Prabowo (Presidente del Partido Gerindra) quien concurría como Presidente en las elecciones legislativas, ya que el Partido Gerindra perdió un escaño en Pekalongan Regency DPRD. De esta manera el efecto 'coattail' no funcionó bien.

Palabras Clave: Efecto 'coattail', Partido Gerindra, Elecciones Concurrentes.

Copyright (C) UNISCI, 2019.

Las opiniones expresadas en estos artículos son propias de sus autores, y no reflejan necesariamente la opinión de UNISCI. The views expressed in these articles are those of the authors, and do not necessarily reflect the views of UNISCI.

\footnotetext{
${ }^{1}$ Ratnawati is Lecturer of the Department of Politics and Government Faculty of Social and Political Sciences, Universitas Gadjah Mada,

E-mail: <ratnaugm@ugm.ac.id>.

${ }^{2}$ Davit Romansa isAlumni of the Postgraduate Program in the Department of Politics and Government Faculty of Social and Political Sciences.

E-mail: <davitromansa01@gmail.com>

DOI: http://dx.doi.org/10.31439/UNISCI-90

${ }^{3}$ Impacto positivo de un candidato sobre el éxito de otros candidatos en elecciones concurrentes
} 


\section{Introduction}

Elections are an important tool in a democratic country and a tangible form of the realization of procedural democracy. For Indonesia, elections are one of the important pillars of democracy, as well as an instrument for respecting and promoting the human rights of citizens, something fundamental and imperative for any government, promoting, at the same time, the establishment and organization of democratic parties as better as possible.

The first elections in Indonesia took place in 1955 in the Old Order era. Subsequently took place in 1971, 1977,1982, 1987, 1992 and 1997 in the New Order era. Then in the reformation era, elections were held in 1999. After that, in 2004, 2009 and 2014, the DPR, DPD, DPRD (Province and Regency/City) legislative elections were held as well as the direct election of the President and Vice President. So far, the elections had been held separately. However, since the Constitutional Court Decision Number 14/PUU-XI/2013 on Testing of Law Number 42 Year 2008 concerning general elections of President and Vice President was delivered, the concept of simultaneous elections was born. The simultaneous election started in 2019.

The simultaneous elections in 2019 had many effects both at the national and regional levels. One of them is related to the strategy used by the party to win the legislative elections both at the central and provincial and district / city levels. In the 2019 simultaneous elections, the Gerindra Party selected Prabowo Subianto who was paired with Sandiaga Uno as the candidate in the presidential election. With the provision of its leading political cadres to contest the presidential election, the Gerindra Party expected that Indonesian voters would support their candidates and win legislative elections at both the central and provincial and district / city levels. In this case, the Gerindra Party used a coattail effect strategy to win the legislative elections.

Gerindra Party in Pekalongan Regency has been chosen to be the object of this research because Gerindra Party was a new political party that won a high vote in the 2014 legislative election compared to old parties such as Partai Kebangkitan Bangsa (PKB), Partai Persatuan Pembangunan (PPP), and Partai Demokrasi Indonesia - Perjuangan (PDI-P). In the legislative elections in Pekalongan Regency which dominated the majority of votes was PDI-P which was supported by nationalist groups and lower-class people and PKB which was culturally supported by Nahdlatul 'Ulama (NU) citizens. However, in the 2014 legislative elections, Gerindra Party was able to obtain 7 seats out of a total of 45 seats in Pekalongan Regency DPRD, and ranked third in the most seats after PDI-P and PKB. The acquisition of Gerindra Party seats in the 2014 legislative elections in Pekalongan Regency was one of their achievements.

Based on the achievements obtained in the 2014 legislative election, Gerindra Party in Pekalongan Regency was targeting to win 10 seats in Pekalongan Regency DPRD in the 2019 legislative election, so that in 2020 Gerindra Party could present Regent candidates without forming a coalition with other parties. In addition, Gerindra Party in Pekalongan Regency also has the target to increase, and even win, Prabowo Subianto's votes in Central Java in the presidential election.

With this simultaneous election, Gerindra Party was trying to renew its usual strategy. At this time, Gerinda Party has used a sociological and personal strategy, namely by approaching the community, prospective cadres, and figures who have influence in society. In addition to this strategy, in the 2019 legislative elections Gerindra Party also used a coattail effect strategy. 
Based on the description above, the focus of the question to be answered in this article is how the coattail effect worked effectively for increasing the number of votes of Gerindra Party in the 2019 Legislative election in Pekalongan Regency.

To answer this question, a qualitative research method was used to interpret the phenomena in certain social contexts. The data collected was the primary data obtained directly in the field from research informants through in-depth interviews. The main informants of this research include the management of Gerindra Party in Pekalongan Regency, legislative candidates in each electoral district in Pekalongan Regency, community leaders in each electoral district in Pekalongan Regency, and several influential religious figures in Pekalongan Regency. In addition, researchers also collected secondary data in the form of documents, including data on permanent voter list data (DPT) in Pekalongan District, data on the identity of legislative candidates, and documents on the results of legislative elections in the year observed. The collected data are later analyzed qualitatively, with stages of data categorization, data reduction, and data analysis using the principle of triangulation and drawing conclusions.

\section{The Concept of Simultaneous Election}

The general elections held after the legislative elections resulted in a fragile coalition of political parties. Experience shows that the results from four elections in the post-reform era often give rise to a government that is "divided" (devided government) ${ }^{4}$. This is indicated by the number of conditions agreed, including alternating between and balancing between the House of Representatives and the President, conditions that do not work well. The Presidential and VicePresidential candidate pairs often make short-term partnerships with political parties that make possible to share relations between rising political parties. In practice, the proposal of a pair of candidates for President and Vice President from political parties does not need the creation of a joint political party, so that no one is able to simplify the party system. In fact, the Indonesian party system is increasingly fragmented. Simultaneous elections are answers to the above questions. In simultaneous elections, a solid collaboration between political parties in government can be forged because there is sufficient time for the consitution of the government.

Geys ${ }^{5}$ states that in general, simultaneous elections or commonly referred as concurrent elections are elections held for the election of several democratic institutions at the same time. These types of elections include executive and legislative elections at various levels in the country concerned, which range from national, regional to local elections. In the use of concurrent election designs, a widely used practice is the merging of executive elections with legislative elections. This design is widely used in Latin American countries. Not only at the national level, simultaneous elections in several countries are also carried out by combining national elections with regional or local elections. In the United States, for example, in several states, elections not only elect the president, members of the congress and senate at the central level, but at the same time also hold elections for governors and legislators at the state level. ${ }^{6}$

While Hanan ${ }^{7}$ argued that the implementation of simultaneous elections would not necessarily have a positive impact on strengthening multiparty presidential systems. There are many variables that must be combined, a combination of electoral systems such as plurality and Majority Run Off (MRO). The effects can be different when combined with simultaneous

\footnotetext{
${ }^{4}$ Ratnia Solihah: "Peluang dan tantangan pemilu serentak 2019 dalam perspektif politik" in Jurnal Ilmiah Ilmu Pemerintahan Vol.3, $\mathrm{n}^{\circ} 1$ (2018), pp.73-88, at: https://ejournal2.undip.ac.id > d

${ }^{5}$ Syamsuddin Haris (et.al) (2014). "Pemilu Nasional Serentak 2019", at http://www.rumahpemilu.com/public/ doc/2015_02_06_01_35_09_EXECUTIVE SUMMARY PEMILU SERENTAK 2019.pdf88, pg. 15.

${ }^{6}$ Ibid, pg. 16.

${ }^{7}$ Djajadi Hanan (2016): "Memperkuat Presidensialisme Multipartai di Indonesia: Pemilu Serentak, Sistem Pemilu dan Sistem Kepartaian” in Jurnal Universitas Paramadina (the Journal of Paramadhina University), Vol. 13, pg.1451-1475.
} 
executive-legislative elections. General findings in various studies, especially from multiparty presidential systems in Latin America show that the combination of the presidential election system with the plurality formula with the legislative elections simultaneously tends to help to simplify the party system. But this still depends, for example, on how many presidential candidates compete. If there are many presidential candidates, the reductive impact of the plurality system on the legislative party system tends to fade.

Another view states that the simultaneous election implementation is an alternative formula for changes in the political system and government. This is based on experience and efforts done to overcome various existing problems, namely: (a) being the basis for the realization of a strong and stable presidential government system, (b) facilitating the emergence of a simplified party system, through providing incentives for political parties to build culture and the institutionalization of sustainable democratic politics (alliances, coalitions, combinations and or mergers), (c) encouraging the formation of more effective parliaments, (d) creating a simpler, shorter time, and low cost election system both in legislative and presidential elections, (e) creating space for the emergence of focus issues in the election, which are national issues and which are local issues, (f) opening space for participation in strengthening the preferences and strategies of the people (voters) in elections based on local and national issues, ( $g$ ) So that the above objectives can be effectively realized, then the presidential election system will run with a reduced threshold (majority conditional) is the main choice. The requirements applied are: President and Vice-President pair is elected in the first round, if they won $45 \%$ of the vote with a difference of $5 \%$ from the second candidate, or $40 \%$ of the vote with a difference of $10 \%$ from the vote of the second candidate. ${ }^{8}$

The design of simultaneous elections in most other countries, as suggested by Jones and many other researchers in Latin American, states that the legislative and executive election system in a multiparty presidential system must combine the simultaneous implementation time and proportional system in legislative elections and the plurality systems for determining the winner in the presidential election. The plurality system actually tends to result in result in the submission of a few candidates for presidential elections. During presidential elections, supporters of the candidates in this system tend to ignore non-competitive candidates so they can focus on the top two candidates. This encourage the inter-party coalition process from the beginning because there is only one round in the elections. Parties whose candidates are less competitive tend to drop their candidates and endorse one of the two most competitive candidates in the hope of getting political concessions after the presidential election. The impact -reduction of the plurality system- has no effect on the presence of these parties in the legislature, assuming legislative elections are carried out with a proportional system. This plurality mechanism influences parties when it is carried out simultaneously with legislative elections. Parties will tend to nominate one of the two most competitive candidates, and end up gathering support from the legislative parties to the two candidates. When one of the candidates wins the presidential election, support for the president in the legislature tends to be given to the majority or close to the majority. Thus, the combination of a pluralistic presidential election system carried out simultaneously with legislative elections is most likely to help strengthen the multiparty presidential systems.

The presidential election system with a majority runoff, on the other hand, tends to produce an inflationary impact on the number of parties, even if it is carried out simultaneously with legislative elections. Parties and candidates competing in this system are more focused on

\footnotetext{
${ }^{8}$ Septi Nur Wijayanti, dan Titin Purwaningsih (2015): “Desain Pemilihan Umum Nasional Serentak dalam Perspektif Hukum dan Politik” (Laporan Akhir Tahun Pertama Penelitian Hibah Bersaing), Yogyakarta, pp. 51, at http://repository.umy.ac.id/bitstream/handle/123456789/2227/Laporan Akhir Desain Pemilihan Umum Nasional Serentak Dalam Perspektif Hukum Dan Politik. pdf?sequence=1\&isAllowed=y
} 
how to advance to the second round. As long as there are no very dominant candidates, a candidate who receives a minimum of one third of the votes has the possibility to advance to the second round. ${ }^{9}$

The issuance of the Constitutional Court Decision No.14/PUU-XI/2013 was a testing for Article 3 paragraph (5), Article 12 paragraph (1) and paragraph (2), Article 14 paragraph (2), and Article 112 of Law No.42 of 2008 concerning the Election of President and Vice President. Some of these articles regulate the provisions for the election of members of Representative Institutions and the presidential election which are held separately. However, based on the decision of the Constitutional Court, the provisions of several articles were declared contrary to the 1945 Constitution and had no binding legal force. The implication of the cancellation was the holding of a simultaneous national general election or the election of members of the Representative Institutions and the presidential election starting with the elections of $2019 .{ }^{10}$

In 2004 and 2009, general elections were held in two stages in which the presidential election was held after the election of the members of the House of Representatives. This separate election mechanism implies that the composition of members of the House of Representatives has been established before the presidential election process. In fact, the composition of the House of Representatives will be a strong indication of what political forces support or oppose a new government, and will determine how the administration runs. As a consequence, presidential candidates are forced to negotiate and bargain with political parties who win the election to ensure the smooth running of his administration if the candidate is elected.

Negotiations and bargaining are in fact having more tactical and short-term characteristics than strategical and longer-term. Therefore, the President in fact becomes very dependent on political parties, so as to reduce the position of the President in exercising government power according to a presidential government system. For this reason, the structuring of the electoral system by the Constitutional Court aims to make the electoral system better and be able to produce qualified presidents and vice presidents, and be able to resolve national and state problems. Presidential elections conducted after the legislative elections (the elections were not simultaneous) had caused the electoral system and the presidential electoral system to be somewhat out of the constitutional track, so, some provisions in the presidential election law governing the matters had to be cancelled. According to Prasetyoningsih ${ }^{11}$, the decision of the Constitutional Court is a good and very acceptable decision, with various arguments in favor: (a) elections which are not held simultaneously do not strengthen the presidential government system; (b) simultaneous elections constitute the mandate of the constitution, (c) they will lead to the effectiveness and efficiency of the holding of elections, as well as support the right of citizens to vote intelligently, so simultaneous elections will indeed be more efficient in terms of its implementation funding.

There are several advantages in holding simultaneous executive-legislative elections. According to Mellaz ${ }^{12}$, There are various factors which become the background and, at the same time, are considered as advantages that holding the simultaneous election have. In many

\footnotetext{
${ }^{9}$ Ibid, pg. 52.

${ }^{10}$ Decision of the Constitutional Cour, R. I. (2013). Number 14/PUU-XI/2013 on the Testing of Law No. 42 Year 2008 regarding the Election of President and Vice President, pp. 85-87.

${ }^{11}$ Prasetyoningsih Nanik (2014): "Dampak Pemilihan Umum Serentak bagi Pembangunan Demokrasi Indonesia". Jurnal Media Hukum (, 21(2), pg. 254, at https://journal.umy.ac.id/index.php/jmh/article/view/1190

${ }^{12}$ Mellaz August (2016): Efektivitas Pemerintahan dan Pelembagaan Sistem Kepartaian Melalui Pelaksanaan Keserentakan Pemilu Nasional, at https://www.spd-indonesia.com/journals/efektivitas-pemerintahan-danpelembagaan-sistem-kepartaian.html
} 
countries, there are significant advantages in holding simultaneous elections. First, the elected president will have a stronger legitimacy since he wins both the popular vote and parliament support. Second, there is a higher possibility of a presidential candidate to win the election in the first round. Third, simultaneous executive-legislative elections could promote the effort to simplify the multi-party systems through; (a) Incentives for political parties to form alliances, form coalitions, or join in both presidential and legislative elections; (b) narrowing the area of competition and the number of political parties that win legislative seats.

Almost in line with the opinion of the experts above, Ni'matul Huda and M. Imam Nasef also said the same thing, pointing out that the implementation of simultaneous elections is in line with the efforts to strengthen the multiparty presidential system in Indonesia. In addition to creating a coa-tail effect that can produce congruent election results, the elected president is most likely to get adequate support in parliament. Simultaneous elections will also stimulate the formation of a strong coalition. That is because the coalition is built from the beginning before the election, so that it will create a more solid coalition.

\section{The Concept of Coattail Effect as A Winning Strategy in Legislative Elections}

Coattail effect is a theory that regulates sequential relations, in which the party winning in the legislative election is the party from which the president and vice president are elected. The coattail effect pattern will strengthen the evaluation of party performance while providing opportunities for political parties to work even better as voters elect candidates from the same party. ${ }^{13}$ At first, the term coattail effect was more widely known in the study of political psychology ${ }^{14}$, it is a general term that refers to the results achieved by a party by involving important or famous figures, both directly and indirectly, through a competition. The point is they are people who have been fascinated by the figure or image of a person so that when he wags the tail of his jacket, people are attracted to choose/ elect.

The coattail effect can be interpreted as the influence of figures in increasing the votes of political parties in general elections. The figure can come from a presidential candidate or a vice-presidential candidate who is promoted. The point is that the political parties will get an overwhelming majority of votes in the legislative election if they nominate popular figures and have high electability. ${ }^{15}$ Through the coattail effect, it is hoped that after electing presidential and vice presidential candidates, voters tend to vote for political parties or coalitions of political parties nominating their elected president.

Scientific studies of the coattail effect are generally based on simultaneous election research in a two-party presidential system such as that conducted in the United States (US). In general, it can be concluded that there is a positive relationship between the electoral power of a presidential candidate and the party that carries it. That is, a presidential candidate or a popular president with a high degree of electability, who will provide an electoral positive advantage to the party that support him as a candidate. Conversely, an unpopular presidential candidate with a low electability level will negatively impact the party's votes that nominate him as presidential candidate.

As an illustration, the absolute victory of the Democratic Party, both in the House of Representatives and the US Senate, in the 2008 elections was partly due to the high popularity and electability of Barack Obama who also won the presidential seat. In contrast, the defeat of

\footnotetext{
${ }^{13}$ Armendia Madariaga Amuiz and Ozen Edge H: "Looking for two-sided coattail effects: Integrated parties and multilevel elections in the U.S.", Electoral Studies, no 40 (2015), pp. 66-75, at https://doi.org/10.1016/j. electstud.2015.06.006, pp. 66-75.

${ }^{14}$ Ridwan (2015): "Presidential Treshold", at http://jonathanparhusip.com/2015/11/04/coattail-tail-effectpsikologi-politik/amp

${ }^{15}$ Djajadi Hanan (2018): “Efek Ekor Jas”, at http://www.saifulmujani.com/blogs/efek-ekor-jas
} 
the Republican Party, both in the House of Representatives and the US Senate in the elections was partly due to the low popularity and acceptance of the US community towards George W Bush that the party nominated in the previous election. As a result of this coattail effect, in every House of Representatives and Senate election which takes place every two years, there is always a phenomenon that the candidates strive to associate themselves with popular presidential candidates

This is what happened in the 2018 US elections, when a third of Republican Senate members tried to distance themselves from Donald Trump as far as possible. President Trump is a US president who is very unpopular in American history. Thus, the coattail effect is a very important phenomenon in the simultaneous election cycle in a multiparty presidential system. In a multiparty system in which the president is nominated by a coalition of supporting parties, there is certainly a positive relationship between the presidential candidate and the party from which the president is from. Although still limited in number, scientific studies also show a positive relationship between the presidential candidates and the electoral power of the coalition members supporting the presidential candidates.

In this regard, Ferejohn dan Fiorina ${ }^{16}$ emphasizes the time factor for the election of parliament members and the president as the main factors causing adivided government as a result of the absence of the coattail effect. According to him, the government is divided when legislative members and executive officials are elected at different time periods and/or in different ways. The rise of a divided government is not due to the use of multiparty systems and proportional elections. The dual party system and majoritarian elections are also equally likely to contribute to a legislative majority that is not the same asthe majority created by political partiessupporting the president. ${ }^{17}$ Thus, in creating an effective presidential government, the problem is not to replace the multiparty system and proportional elections, but rather how to design the existing party system and electoral system in order to avoid the emergence of a divided government. One way to avoid this result is to organize the executive and legislative elections simultaneously, because in simultaneous elections, the emergence of the coattail effect is very possible.

Fiorina's argument is in line with Shugart's thesis ${ }^{18}$ that if the timing of the presidential election is synchronized with the legislative elections, it will cause a coattail effect. The results of the presidential election will affect the results of legislative elections. It means that the voters will elect the president as well as political parties that form a coalition with supporters of the president.

The coattail effect thesis shows that the timing of elections can overcome the problem of disharmony between the executive and the legislature. If the timing of the presidential election coincides with the legislative election, the presidential election will affect the legislative elections. It means that the voters will elect the president and elect political parties that support the president of his choice.Simultaneous elections can also be designed to influence not only the outcome of the presidential but also legislative elections..Usually, the consideration is to influence the results of presidential elections by using the results of legislative elections as one of the bases for determining the winner. The party with the most votes can send its presidential candidate to the presidency even though the outcome is not necessarily the best.

\footnotetext{
${ }^{16}$ JA. Ferejohne and MP. Fiorina, M.P (1985). "Incumbency and Realignment in Congressional Elections", in J.E. Chubb dan P.E. Peterson, The New Direction in American Politics. pp. 91-115

${ }^{17}$ Septi Nur Wijayanti, S. N., \& dan Titin Purwaningsih, T. (2015). op. cit p. 44.

${ }^{18}$ Ibid.
} 


\section{The Effectiveness of the Gerindra Party CoatTail Effect Strategy in 2019 Simultaneous Elections in Pekalongan Regency}

\subsection{Short Profile of Gerindra Party}

Gerindra Party was founded on February 6, 2008 by Prabowo Subianto ${ }^{19}$ and his younger brother, Hashim Djojohadikusumo ${ }^{20}$. Apart from being the founder, Prabowo was also the General Chairperson of the Board of Trustees of the Party. Therefore, this party has a strong institutional structure and a very influential figure. Structurally, Gerindra Party has a uniform structure, starting at the central/national level to the branch/district/city level. Besides the Chairperson and his staff, there are bodies and hands within the party organizational structure ${ }^{21},{ }^{22}$ which are in charge of helping the party's operation.

With the General Chairperson and the board of founders of the Party being held by the same people, as well as an established organizational structure, Gerindra Party, as a party with strong institutions have the utmost confidence to declare itself as a new party contesting in the 2009 election, Gerindra Party conducted a conference/congress aimed at changing the form/structure of the party. This shows that Prabowo, as the chairperson and the chairperson of the board of founders, was always obeyed by the party's members and cadres. This strong structure has become one of the strong assets for this party to contest in politics, both in the legislative election and presidential election. The advantage gained by the Gerindra Party in the 2019 elections could induce the nomination of Prabowo Subianto as a Presidential candidate.

\subsection{Students of Islam - Business as the Dominant Character of the People of Pekalongan Regency}

Pekalongan Regency is one of 35 regencies/cities in Central Java Province, located in the Pantura (North Coast) area of the Java Sea with the direction extending to the south with Kajen as the capital of the government. Administratively, Pekalongan Regency consists of 19 subdistricts, 272 villages and 13 village offices. Pekalongan has always been synonymous with batik and batik has become the main icon of this area, so that this area gets the title as the world city of batik.

Pekalongan Regency is called middle Indonesia ${ }^{23}$, which is a combination of rural and urban areas. ${ }^{24}$ The social space is made up by a settled middle-class group and a group of poor

\footnotetext{
${ }^{19}$ Prabowo Subianto is the son of a well-known Indonesian economist, Prof. Dr. Soemitro Djojohadikusumo and son-in-law of Indonesia's former 2nd President, Suharto. Before becoming active in politics, he was a general and a senior Indonesian military officer, with his last position as Commander in Chief of the Strategic Reserve Command. During his career in politics, he had held various positions, and finally as Commander General in the Special Forces Command. In the 2009 presidential election, Prabowo Subianto was a vice presidential candidate, paired with Megawati Soekarno Putri as a presidential candidate. Then in the 2014 presidential election, Prabowo along with Hatta Rajasa ran for president candidate. In the 2019 presidential election, Prabowo ran for president candidate along with Sandiaga Salahuddin Uno.

${ }^{20}$ Hashim Djojohadikusumo is Prabowo Subianto's younger brother and is a well-known Indonesian businessman.

${ }^{21}$ The institutions are Badan Disiplin Partai, Badan Kajian dan Kebijakan Partai, badan Kesehatan Indonesia Raya (KESIRA), Badan Komunikasi, and Badan Pendidikan dan Latihan 9 Party Discipline Agency, Party Policy and Study Agency, Greater Indonesia Health Agency (KESIRA), Communication Agency, and Education and Training Agency). These institutions are tasked to assist the party in carrying out the party's functions.

${ }^{22}$ Existing party hands include Tunas Indonesia Raya (TIDAR) aimed at young people of the Gerindra Party and Perempuan Indonesia Raya (Women of the Great Indonesia) (PIRA) which aims to capture the aspirations of women in Indonesia. These party hands are more flexible and usually belong to the community/groups in society. ${ }^{23}$ Van Klinken in Savirani, Amalinda. 2015. Business and politics in provincial Indonesia: The batik and construction sector in Pekalongan, Central Java, Amsterdam, University of Amsterdam, p. 42

24390.870 people live in the Regency. Based on its geographical characteristics, social space, economic, and political condition, Pekalongan is categorized as middle Indonesia. These conditions suggest that Pekalongan should be socially and economically driven by its own market and does not depend much on the state.
} 
people. In economic and political terms, the people in Pekalongan are a combination of market participants and formal government institutions. In addition, Pekalongan community is known for having a multicultural character, because the area was a stopover for traders in 1846 . Various ethnic traders stopped by and settled in Pekalongan, ranging from Chinese, Indians, Arabs, and Hadramauts which are located in the southern Arab States. The diversity of the people in Pekalongan began with the presence of Arab traders in 1846. ${ }^{25}$

Later, in the 19th century Chinese traders began to come to Pekalongan as an important place for trade. There are at least a few ethnic Chinese groups in Pekalongan, such as: Hokkien, Kei, and Bagan. Hokkien groups are those who come first in Pekalongan and come from the native Hokkien community in China. The next was the Chinese Kei group which migrated to Pekalongan and was followed by the Chinese Bagan group which had already resided in Bagansiapiapi, West Sumatra. These three Chinese ethnic groups exert a great influence on the development of the society in Pekalongan. The Hokian group is active in the textile industry (convection), the Kei group in the retail of chemical dyes, and the Bagan group in the field of fisheries. ${ }^{26}$ In addition, in Pekalongan community, there are also groups of people of Arab descents (both those who have direct lineage with the Prophet Muhammad s.a.w who are referred to as the Haba ib group or those who do not have direct lineage called the Non-Haba ib group). The Haba ib group is more focused on activities related to religion, while those who are non-Haba ib groups are more focused on business activities. ${ }^{27}$

The presence of various ethnic groups in Pekalongan has made people familiar with cultural and religious differences.

Besides being well-known as a batik producer and business/trading, the Pekalongan community is also well-known as a religious community, so it is identified as a santri community. As a santri community, the presence and influence of Islamic religious leaders is very strong, including Habib Lutfi bin Ali Yahya, Habib Bagir, and Kyai Thohir. Ideologically, the Islamic group that is rapidly developing and influencing Pekalongan community is the orthodox traditionalist of Nahdlatul Ulama (NU) group. In interacting with the diverse Pekalongan community, this group is making secretions with the local culture. This made the NU group labeled as a traditionalist group.

In the Pekalongan community, the Habib and Kyai/ Clerics of NU have a great influence, especially on the Muslim community. Generally, the Kyai has a boarding school and a large number of students. The following table presents the number of Islamic boarding school and its students in Pekalongan residency. ${ }^{28}$

\footnotetext{
${ }^{25}$ Vuldy and Majlis (et al) in Ibid, p. 86.

26 Thohir in Ibid, p. 86.

${ }^{27}$ Mobini-Kesheh, N: "The Hadrami Awakening: Community and Identity in the Netherlands East Indies, 19001942. no. 28, (1990), SEAP Publication.

${ }^{28}$ In the regional government system according to Law No. 1 of 1957 , Pekalongan Regency is included in the Pekalongan Residency, which consists of 7 Regencies / Cities.
} 
Table 1. The Number of Islamic Boarding School and its Students in the Areas of Pekalongan Residency ${ }^{29}$

\begin{tabular}{|l|l|l|}
\hline Area & Number of schools & Number of students \\
\hline Pekalongan City & 30 & 3,773 \\
\hline Pekalongan Regency & 82 & 12,623 \\
\hline Batang Regency & 57 & 7,446 \\
\hline Pemalang Regency & 37 & 9,874 \\
\hline Tegal Regency & 40 & 17,986 \\
\hline Brebes Regency & 103 & 14,635 \\
\hline Tegal City & & 1,435 \\
& 7 & \\
\hline
\end{tabular}

Source: Vikarusyda (2015)

The influence of the Kyai/ the clerics is not only in the religious field, but also in the political field. They also helped to ensure political stability and influence the dynamics of politics in Pekalongan Regency. Opinions or teachings of the clerics have an enormous influence on the community, and it is difficult for the community not to follow the recommendations of the clerics including the recommendation for the political choice. Therefore, in the electoral process in Pekalongan Regency, political parties and candidates contest the votes of these clerics. They are competing to get the blessing and support of the clerics and habib. ${ }^{30}$

\subsection{Gerindra Party and Legislative Election in Pekalongan Regency: Minorities Struggle among the Majority}

In the context of conducting legislative elections and determining the number of seats/representatives in the DPRD, Pekalongan Regency is divided into 5 (five) electoral districts based on the sub-districts and population as follows:

\footnotetext{
${ }^{29}$ Vikarusyda, M. (2015): Peran Kyai yang Mempengaruhi Pilihan Politik Masyarakat terhadap Perekonomian Daerah: Suatu Kajian Ekonomi Politik (The Role of Clerics That Influences Society's Political Choices in the Regional Economy: A Study of Political Economy), Surakarta, Universitas Negeri Solo.

${ }^{30}$ Vuldy, C: "La communaute Arabe de Pekalongan", Archipel 30, no 1 (1985), 95-119
} 
Table 2. Number of Electoral Districts in Pekalongan Regency

\begin{tabular}{|c|c|c|c|}
\hline Electoral Disctrict & District & $\begin{array}{l}\text { Number of } \\
\text { People }\end{array}$ & $\begin{array}{l}\text { Number of } \\
\text { seats }\end{array}$ \\
\hline \multirow{3}{*}{1} & Kajen & 58,692 & \multirow{3}{*}{7} \\
\hline & Paninggaran & 35,388 & \\
\hline & Kandangserang & 33,494 & \\
\hline \multirow{3}{*}{2} & Bojong & 63,229 & \multirow{3}{*}{10} \\
\hline & Sragi & 62,580 & \\
\hline & Kesesi & 61,909 & \\
\hline \multirow{4}{*}{3} & Tirto & 71,779 & \multirow{4}{*}{10} \\
\hline & Siwalan & 37,992 & \\
\hline & Wonokerto & 47,402 & \\
\hline & Wiradesa & 59,501 & \\
\hline \multirow{4}{*}{4} & Kedungwuni & 97,743 & \multirow{4}{*}{11} \\
\hline & Wonopringgo & 42,795 & \\
\hline & Buaran & 45,893 & \\
\hline & Karangdadap & 36,283 & \\
\hline \multirow{5}{*}{5} & Doro & 38,078 & \multirow{5}{*}{7} \\
\hline & Karanganyar & 37.117 & \\
\hline & Lebakbarang & 10.428 & \\
\hline & Petungkriyono & 12.723 & \\
\hline & Talun & 27.066 & \\
\hline $\begin{array}{l}\text { TOTAL: Number of seats } \\
\text { in the Pekalongan } \\
\text { Regency Regional House } \\
\text { of Representatives }\end{array}$ & & & 45 \\
\hline
\end{tabular}

Source: Regional House of Representatives of Pekalongan Regency

Thus, the number of seats contested by political parties in the legislative election in the Pekalongan Regency Regional House of Representatives is 45.

According to the character of the people who are students of Islam-businessmen and patronized to NU clerics, the political parties that have been dominant and gained seats in the legislative elections in Pekalongan Regency are PKB and PDI-P. In the midst of the character of the Pekalongan community, in the 2009 election - the first election that was followed -, Gerindra Party succeeded in gaining one seat in the Pekalongan Regency, the legislative candidate who came from electoral district 5. ${ }^{31}$ Also in 2009, Gerindra Party nominated Prabowo Subianto as a candidate for Vice President in pair with Megawati Soekarno Putri as a Presidential candidate (from PDI-P), because Gerindra Party successfully met the presidential

${ }^{31}$ The results of an interview with the Secretary of the Regional Parliament of Pekalongan Regency on April 2, 2019. 
threshold. That is, Gerindra Party as a new party at that time was able to compete with major parties, especially with PKB and PDI-P in Pekalongan Regency. And in the 2014 legislative elections, there was an increase in the acquisition of a significant number of seats, namely getting 5 seats in the Pekalongan District Parliament. This can be seen in the following table:

Table 3. Number of Seats Obtained in Pekalongan District Parliament in the 2014 Legislative Election

\begin{tabular}{|l|l|l|}
\hline No. & Political Parties & $\begin{array}{l}\text { Number of seats } \\
\text { acquired (people) }\end{array}$ \\
\hline 1. & Partai Kebangkitan Bangsa (PKB) & 12 \\
\hline 2. & Partai Demokrasi Indonesia-Perjuangan (PDI-P) & 11 \\
\hline 3. & Partai Gerindra & 5 \\
\hline 4. & Partai Golkar & 5 \\
\hline 5. & Partai Persatuan Pembangunan (PPP) & 4 \\
\hline 6. & Partai Amanat Nasional & 4 \\
\hline 7. & Partai Demokrat & 2 \\
\hline 8. & Partai Kesejahteraan Sosial (PKS) & 1 \\
\hline 9. & Partai Hanura & 1 \\
\hline TOTAL & Jumlah kursi DPRD Kabupaten Pekalongan & 45 \\
\hline
\end{tabular}

Source: Regional House of Representatives of Pekalongan Regency

This result is an extraordinary achievement for the Gerindra Party, because it was obtained through a struggle in the majority of Pekalongan people who are religious and having NU ideology, as well as in contestation with large and long-established political parties in Pekalongan Regency.

The factors generating the increase in the number of seats obtained by the Gerindra Party in the 2014 legislative elections in the Pekalongan Regency DPRD were the following: (1) the strength of the party's institutional structure, in which the Chairperson and the Board of Founders were held by the same figure, namely Prabowo Subianto and (2) the existence of a strong figure give a coattail effect to the party and as one of the determining factors for the community in deciding which legislative candidate to choose, because in the 2014 legislative election, Prabowo became a Presidential candidate paired with Hatta Rajasa as a Vice President candidate.

\subsection{Commodification of Prabowo and Coattail Effect in the 2019 Legislative Elections in Pekalongan Regency}

The 2019 simultaneous elections were held on April 17, 2019 to simultaneously elect legislative members (national, provincial and district/city level) and elect the President and Vice President. Gerindra Party for the third time again proposed Prabowo Subianto as a Presidential candidate paired with Sandiaga Uno as a Vice Presidential candidate. Prabowo Subianto's nomination as presidential candidate in the 2019 presidential election was expected to influence the acquisition of Gerindra Party seats. This is consistent with the opinion expressed by Moos that "the President candidate who advances from one political party will give a significant vote to the 
legislative candidates in the party". ${ }^{32}$ This is what is called the coattail Effect. Especially for those who are the first to participate in political contestation. This is very helpful to candidates in the regions, because the public will be facilitated to remember parties and presidential candidates. Thus, when they are required to vote for candidates in legislative elections, it is easy for voters to choose parties or legislative candidates from contesting presidential candidates. The coattail Effect provides feedback from not only the President to candidates, but also between candidates to the President.

In the 2019 legislative elections in Pekalongan Regency, Gerindra Party still strongly believed in the coattail effect, so that it was still optimistic to gain votes and seats in the Pekalongan Regency as in the 2014 legislative elections. Taking into account the character of the majority of Pekalongan community, Gerindra Party with nationalist character-building coalitions with Islamic parties, namely PKS and PAN, in an effort to capture the votes of the groups of students of Islam. This is in accordance with Gerindra Party's policy at the national level, moreover because the vice-presidential candidate paired with Prabowo Subianto is supported by PAN and PKS.

In the 2019 presidential election, there were two candidates, namely Joko Widodo Ma'ruf Amin and the Prabowo-Subianto-Sandiaga Salahudin Uno. Based on the results of the official recapitulation of the General Election Commission of the Republic of Indonesia (KPU RI) as the election organizer, the percentage of votes obtained by the pair of Joko Widodo Ma'ruf Amin was 55.39\% and the pair Prabowo Subianto-Sandiaga Salahudin Uno obtained $44.61 \%$.

The acquisition of seats and votes by political parties at the national level in the 2019 legislative elections is as follows:

Table 4. Recapitulation of Party's Seats and Votes in the 2019 Legislative Election (National)

\begin{tabular}{|l|l|c|l|l|}
\hline No & Political Parties & $\begin{array}{l}\text { Number of } \\
\text { seats }\end{array}$ & $\begin{array}{l}\text { Number of } \\
\text { votes }\end{array}$ & $\begin{array}{l}\text { Percentage } \\
(\%)\end{array}$ \\
\hline 1 & PDI Perjuangan & 128 & 27.503 .961 & 19,33 \\
\hline 2 & Partai Golkar & 85 & 17.229 .789 & 12,31 \\
\hline 3 & Partai Gerindra & 78 & 17.596 .839 & 12,57 \\
\hline 4 & Partai Nasdem & 59 & 12.661 .792 & 9,05 \\
\hline 5 & Partai Kebangkitan Bangsa (PKB) & 58 & 13.570 .970 & 9,69 \\
\hline 6 & Partai Demokrat & 54 & 10.876 .057 & 7,77 \\
\hline 7 & Partai Keadilan Sejahtera (PKS) & 50 & 11.493 .663 & 8,21 \\
\hline 8 & Partai Amanat Nasional (PAN) & 44 & 9.572 .623 & 6,84 \\
\hline 9 & $\begin{array}{l}\text { Partai Persatuan Pembangunan } \\
\text { (PPP) }\end{array}$ & 19 & 6.323 .147 & 4,52 \\
\hline 10 & Partai Berkarya & 0 & 2.902 .495 & 2,09 \\
\hline 11 & Partai Solidaritas Indonesia (PSI) & 0 & 2.650 .361 & 1,85 \\
\hline
\end{tabular}

\footnotetext{
${ }^{32}$ Armendia Madariaga Amuiz and Ozen Edge H.: "Looking for two-sided coattail effects: Integrated parties and multilevel elections in the U.S", Electoral Studies, 40, (2015), pp.66-75, at https://doi.org/10.1016/j. electstud.2015.06.006, pp. 66-75.
} 


\begin{tabular}{|l|l|l|l|l|}
\hline 12 & Partai Hanura & 0 & 2.161 .507 & 1,54 \\
\hline 13 & Partai Bulan Bintang (PBB) & 0 & 1.990 .848 & 0,79 \\
\hline 14 & Partai Perindo & 0 & 3.738 .320 & 2,07 \\
\hline 15 & $\begin{array}{l}\text { Partai Keadilan dan Persatuan } \\
\text { Indonesia (PKPI) }\end{array}$ & 0 & 312.775 & 0,22 \\
\hline 16 & Partai Garuda & 0 & 702.536 & 0,5 \\
\hline
\end{tabular}

Source: KPU, 2019.33

Table 5. Number of Seats Obtained in the Regional House of Representatives of Pekalongan Regency in the 2019 Legislative Election

\begin{tabular}{|l|l|l|}
\hline No. & Political Parties & $\begin{array}{l}\text { Number of seats } \\
\text { obtained }\end{array}$ \\
\hline 1. & Partai Kebangkitan Bangsa (PKB) & 15 \\
\hline 2. & Partai Demokrasi Indonesia-Perjuangan (PDI-P) & 11 \\
\hline 3. & Partai Gerindra & 5 \\
\hline 4. & Partai Persatuan Pembangunan (PPP) & 5 \\
\hline 5. & Partai Golkar & 4 \\
\hline 6. & Partai Amanat Nasional & 4 \\
\hline 7. & Partai Kesejahteraan Sosial (PKS) & 1 \\
\hline TOTAL & Jumlah kursi DPRD Kabupaten Pekalongan & 45 \\
\hline
\end{tabular}

Source: Regional House of Representatives of Pekalongan Regency

Table 6. Comparison of the Number of Seats Obtained by the Gerindra Party in the Regional House of Representatives of Pekalongan Regency Legislative Elections in 2009, 2014 and 2019

\begin{tabular}{|l|l|l|}
\hline Election year & $\begin{array}{l}\text { Prabowo Subianto's position in the } \\
\text { presidential election }\end{array}$ & $\begin{array}{l}\text { Seats obtained in the } \\
\text { legislative llection }\end{array}$ \\
\hline 2009 & Vice President Candidate & 1 \\
\hline 2014 & President Candidate & 5 \\
\hline 2019 & President Candidate & 5 \\
\hline
\end{tabular}

Source: Data processing results from the Regional House of Representatives of Pekalongan Regency

On the basis of the coattail effect theory, the commodification of Prabowo as a Presidential candidate in the 2019 presidential election, affected the increased acquisition of Gerindra Party seats in the 2019 legislative election in Pekalongan Regency Regional House of Representatives; but from the data in tables 5 and 6 , it turns out that the acquisition of Gerindra Party seats has not increased compared to the 2014 legislative elections, which still only gets 5 seats. This means that the coattail effect does not work well in Pekalongan Regency. The coattail effect that was predicted to benefit Gerindra Party with Prabowo Subianto as a candidate in

\footnotetext{
${ }^{33}$ This article has been published on Kompas.com with the title "Complete Results of the Seats Obtained of the House of Representatives in 2019-2024", at https://nasional.kompas.com/read/2019/08/31/11152361/hasillengkap-perolehan-kursi-dpr-2019-2024?page $=2$.
} 
the presidential election this time, did not bring significant effect in increasing the acquisition of Gerindra Party seats in Pekalongan Regency.

There are several reasons that caused that the coattail effect of Gerindra Party did not work well in the 2019 legislative elections in Pekalongan Regency. First, Gerindra Party competed amidst the majority of the Islamic boarding school student community which was still strong focusing on identity politics and showing a strong fanaticism against the NU and the parties affiliated with NU, namely PKB. Second, despite forming a coalition with PKS and PAN, both were modern Islamic parties, different from PKB, a traditional Islamic party. Third, the figure factor of legislative candidates and money politics influenced people's behavior.

\section{Conclusion}

The theory of the coattail effect used by Gerindra Party in the 2019 simultaneous elections in Pekalongan Regency was not successful. With the coattail effect, Gerindra Party, which nominated Prabowo as a presidential candidate in the 2019 presidential election, hoped to provide positive benefits and increased the acquisition of seats in the legislative election in Pekalongan Regency. However, it did not work well. In the 2019 legislative elections, Gerindra Party did not succeed in increasing the acquisition of the number of seats in Pekalongan Regency Regional House of Representatives. The contributing factors are the strong identity politics and the fanaticism shown by the Pekalongan community against NU and PKB, the different ideologies of Gerindra Party coalition (PKS and PAN) and PKB, and the strong clientelism and money politics among the Pekalongan community.

\section{Bibliography}

Armendia Madariaga Amuiz and Ozen Edge H.: "Looking for two-sided coattail effects: Integrated parties and multilevel elections in the U.S.", Electoral Studies, Vol. 40 (2015), pp. 66-75, at https://doi.org/10.1016/j. electstud.2015.06.006.

Decision of the Constitutional Cour, R. I. (2013). Number 14/PUU-XI/2013 on the Testing of Law No. 42 Year 2008 regarding the Election of President and Vice President.

Ferejohn, John A., and Fiorina, Morris.P: "Incumbency and Realignment in Congressional Elections", in Chubb John E. and Peterson, Paul E (2010): The New Direction in American Politics, Washington DC, Brookings Institution.

Hanan, Djajadi (2018): "Efek Ekor Jas". Author and title at http://www.saifulmujani.com/blogs/efek-ekor-jas

Hanan, Djajadi: "Memperkuat Presidensialisme Multipartai di Indonesia: Pemilu Serentak, Sistem Pemilu dan Sistem Kepartaian" in Jurnal Universitas Paramadina (the Journal of Paramadhina University), Vol. 13 (2016)

Haris, Syamsuddin (et.al) (2014): “Pemilu Nasional Serentak 2019”, at http://www.rumahpemilu.com/public/doc/2015_02_06_01_35_09_EXECUTIVE SUMMARY PEMILU SERENTAK 2019.pdf88.

Kesheh, Natalie Mobini (1999): The Hadrami Awakening: Community and Identity in the Netherlands East Indies, 1900-1942, Cornell, Southeast Asia Program 
Mellaz August (2016). "Efektivitas Pemerintahan dan Pelembagaan Sistem Kepartaian Melalui Pelaksanaan Keserentakan Pemilu Nasional" at https://www.spd-indonesia.com/journals/efektivitas-pemerintahan-dan-pelembagaan-sistemkepartaian.html

Prasetyoningsih, Nanik (2014). "Dampak Pemilihan Umum Serentak bagi Pembangunan Demokrasi Indonesia" in Jurnal Media Hukum Vol.21, $\mathrm{n}^{\circ} 2$ (2014) at http://journal.umy.ac.id/index. php/jmh/article/download/1190/1251

Ridwan (2015): "Presidential Treshold" Author and title at http://jonathanparhusip.com/2015/11/04/coattail-tail-effect-psikologi-politik/amp

Savirani, Amalinda. (2015): Business and politics in provincial Indonesia: The batik and construction sector in Pekalongan, Central Java, Amsterdam: University of Amsterdam.

Solihah, Ratnia: "Peluang dan tantangan pemilu serentak 2019 dalam perspektif politik" dalam Jurnal Ilmiah Ilmu Pemerintahan, Vol.3, n 1 (2018) at: https://ejournal2.undip.ac.id > jiip > article > download

Vikarusyda, M. (2015): Peran Kyai yang Mempengaruhi Pilihan Politik Masyarakat terhadap Perekonomian Daerah: Suatu Kajian Ekonomi Politik, Surakarta, Universitas Negeri Sebelas Maret

Vuldy, C: “La communaute Arabe de Pekalongan”, Archipel, Vol.30, n 1 (1985).

Wijayanti, Septi Nur, S. N., and Titin Purwaningsih. (2015): Laporan Akhir Tahun Pertama Penelitian Hibah Bersaing: "Desain Pemilihan Umum Nasional Serentak dalam Perspektif Hukum dan Politik" (Laporan Akhir Tahun Pertama Penelitian Hibah Bersaing). Yogyakarta, at http://repository.umy.ac.id/ bitstream/ handle/123456789/2227/Laporan Akhir Desain Pemilihan Umum Nasional Serentak Dalam Perspektif Hukum Dan Politik. pdf? sequence $=1 \&$ isAllowed $=y$ 